$1-1-1969$

\title{
Relationship of dietary protein level to carcass characteristics and growth performance of swine
}

\author{
J. L. McBee Jr.
}

Follow this and additional works at: https://researchrepository.wvu.edu/ wv_agricultural_and_forestry_experiment_station_bulletins

\section{Digital Commons Citation}

McBee, J. L. Jr., "Relationship of dietary protein level to carcass characteristics and growth performance of swine" (1969). West Virginia Agricultural and Forestry Experiment Station Bulletins. 576T.

https://researchrepository.wvu.edu/wv_agricultural_and_forestry_experiment_station_bulletins/684 @ WVU. It has been accepted for inclusion in West Virginia Agricultural and Forestry Experiment Station Bulletins by an authorized administrator of The Research Repository @ WVU. For more information, please contact ian.harmon@mail.wvu.edu. 
West Virginia University Libraries 
Digitized by the Internet Archive in 2010 with funding from

Lyrasis Members and Sloan Foundation

http://www.archive.org/details/relationshipofdi576mcbe 
Relationship of Dietary Protein Level To Carcass Characteristics and Growth Performance of Swine

WEST VIRGINIA UNIVERSITY AGRICULTURAL EXPERIMENT STATION

BULLETIN 576T March 1969 


\section{THE AUTHORS}

J. L. McBee, Jr. and D. J. Horvath are Associate Animal Husbandmen; C. Lee and C. W. Scherer are Graduate Research Assistants.

WeST VIRGINIA UNIVERSITY

Agricultural Experiment Station

College of Agriculture and Forestry

A. H. Vanlandingham, Director

MORGANTOWN 


\section{Relationship of Dietary Protein Level To Carcass Characteristics and}

Growth Performance of Swine

J. L. MCBEE, JR., D. J. HORVATH, C. LEE and C. W. SCHERER

SELECTION FOR MEAT TYPE may have altered the ability of $S_{\text {swine to utilize protein, thereby necessitating re-examination of ration }}$ protein levels. Further, input:output values are needed for use in formulating swine rations.

In the study reported here, ration protein was chosen as the principal input, whereas output was lean cuts gained as estimated by the balance-by-slaughter technique. A secondary aim was to compare the classic nitrogen balance with other indices of efficiency of protein utilization.

In addition to examining feedlot performance and carcass characteristics, the effects of dietary protein levels on chemical composition and taste panel score of pork were compared in certain trials of this experiment.

\section{Experimental Procedure}

Five feeding and slaughter trials were conducted with a total of 108 pigs to determine the effect of dietary protein levels on gain in lean cuts. Treatments are shown in Table 1.

The same basic ration formulae (Table 2) were used in all five trials. Protein levels were changed by varying the amounts of No. 2 corn and 50 per cent dehulled solvent process soybean oil meal. For pigs of the same bodyweight the calculated calcium and phosphorus levels were equalized in trials 4 and 5 by adding dicalcium phosphate and sodium phosphate to the diets. An antibiotic supplement was included for these two trials.

Pigs were weighed, allotted to treatment randomly within sex, breed and litter, and placed in concrete-floored pens with self-feeders. Pigs were watered twice daily in concrete troughs for all trials except number 2, for which automatic waterers were used. In all trials except 


\begin{tabular}{ccc} 
& Period & \\
\hline I & II & III
\end{tabular}

A. Crude protein levels fed (calculated), per cent

High

Medium

Low
21

18

15
18

15

12
15

12

9

\section{Trial}

B. Weight limits for respective periods, $l b$.

1 February-June, 1960

2 May-September, 1960

3 December, 1960-May, 1961

4 November, 1964-March, 1965

5 May-August, 1965

$\begin{array}{lrr}\text { weaning - 100 } & 100-150 & 150-200 \\ \text { weaning - 100 } & 100-150 & 150-200 \\ \text { weaning - 75 } & 75-125 & 125-200 \\ \text { weaning - 75 } & 75-125 & 125-200 \\ \text { weaning - 75 } & 75-125 & 125-200\end{array}$

\section{TABLE 2}

Ration Formula

\section{Protein, per cent}

Calculated protein

Protein determined by Kjeldahl analysis of pooled samples
21

20.8
18

17.6
15

15.0
12

12.0

Ingredients

Corn, ground

$50 \%$ soybean oil meal

$17 \%$ dehydrated alfalfa meal

Mineral premix ${ }^{2}$

Ground limestone

Vitamin premix ${ }^{b}$

Antibiotic supplement ${ }^{c}$

$\begin{array}{rrrrr}64.2 & 71.2 & 78.2 & 85.4 & 92.4 \\ 29.4 & 22.4 & 15.4 & 8.2 & 1.2 \\ 3.0 & 3.0 & 3.0 & 3.0 & 3.0 \\ 2.0 & 2.0 & 2.0 & 2.0 & 2.0 \\ 0.4 & 0.4 & 0.4 & 0.4 & 0.4 \\ 1.0 & 1.0 & 1.0 & 1.0 & 1.0\end{array}$

'The mineral premix added $50 \mathrm{ppm} \mathrm{Zn}, 10 \mathrm{mg}$. Fe, $1 \mathrm{mg} . \mathrm{Cu}$, and $10 \mathrm{mg}$. Mn per pound of ration. Zinc was raised to $75 \mathrm{ppm}$ January, 1961, and to $100 \mathrm{ppm}$ November, 1964.

'The vitamin premix added $90 \mathrm{I.U}$. vitamin $\mathrm{D}, 1 \mathrm{mg}$. carotene, $0.5 \mathrm{mg}$. riboflavin, $2 \mathrm{mg}$. calcium pantothenate, $2 \mathrm{mg}$. niacin and $5 \mathrm{mcg}$. $\mathrm{B}_{12}$ per pound of ration.

"Antibiotic supplement provided $20 \mathrm{gm}$. chlortetracycline per $908 \mathrm{~kg}$. of diet in Trials 4 and 5 only.

number 3 the pigs were removed from feed for $24 \mathrm{hrs}$. at approximately $200 \mathrm{lb}$., then slaughtered, and dressed packer style. At the beginning of each trial representative pigs were slaughtered and carcass data were recorded. 
The carcasses were chilled at $36^{\circ} \mathrm{F}$ for 48 hrs. The dressing percentage was obtained from the fasted weight and the weight of the chilled carcass. Backfat thickness was obtained from the average of measurements taken at three positions: the first thoracic, the last thoracic, and the last lumbar vertebra. Carcass length was measured from the anterior elge of the first rib near the vertebral column to the anterior edge of the aitch bone. The carcasses were then cut according to the procedure recommended by the Pork Committee at the Reciprocal Meats Conference (1952). The percentage of lean cuts was calculated from the total weight of four trimmed lean cuts (ham, picnic, Boston butt and loin) and the weight of the chilled carcass or the weight of the fasted animal before slaughtering. The value of gain in lean cuts was obtained from the difference in lean cuts of the experimental animals and that of the random pig from each litter slaughtered at the beginning of the experiment. In a similar manner, percentage of fat cuts was obtained from belly, jowl, leaf fat, backfat and fat trim. A tracing on acetate paper was made of the longissiums dorsi between the 12th and 13th ribs.

\section{Trial 1}

Pigs in trial 1 were twelve Durocs averaging $48 \mathrm{lb}$., sired by the same boar, and from related sows. Two barrows and two gilts from each of three litters were allotted to groups. The four pigs in each protein group were penned together. Two additional pigs were selected from two of the same litters without regard to sex, and slaughtered the day the experiment started.

\section{Trial 2}

The twelve pigs in trial 2 averaged $57 \mathrm{lb}$. and were from one litter of Yorkshires and one Duroc x Yorkshire litter. (The sire of the crossbred pigs was not the same as in trial 1.)

Three barrow's and three gilts were selected from each litter and randomly allotted within sex and litter to treatment. An additional pig from each litter was selected without regard to sex and slaughtered to estimate the initial composition. This study was conducted in the same manner as was trial 1 except that classical nitrogen balance was determined for the barrows for approximately 1 week on each protein level. Details of the method are presented by Scherer (1962). No effort was made to restrict intake of the barrows in the metabolism crates. However, when the barrows were removed from the crates after the second collection period they were much lighter than the gilts and therefore they were penned separately. 
One barrow was sacrificed after the second collection period because of lameness. The amount of feed eaten by this barrow was estimated and substracted from the total for his group. This barrow is excluded except for the second period of the nitrogen balance study.

Due to retarded growth and apparent alternations in the lean:fat ratio in the pigs confined in crates, no further balance studies were conducted.

\section{Trial 3}

The thirty-six pigs in trial 3 were from three litters of Duroc $\mathrm{x}$ (Yorkshire $\mathrm{x}$ Tamworth) and four litters of Durocs. The crossbred sows were littermates and the Duroc sows were littermates. (These Durocs were not related to those used in trial 1. All pigs were sired by the Duroc boar that sired the crossbred pigs in trial 2.)

Average initial weight of the Durocs was $36 \mathrm{lb}$. and of the crossbreds $51 \mathrm{lb}$. Strains and sexes were penned separately so that in this trial separate feed data could be obtained for each sex of each strain on each level of protein.

The first pig in each group to reach $75 \mathrm{lb}$. was slaughtered. Durocs slaughtered at this time were barrows and the crossbreds were gilts. Slaughtering the heaviest pig may have influenced the outcome. However, there is the advantage that the remaining pigs were within a narrow weight range.

At 125 lb., a barrow and a gilt from each strain and each protein level were slaughtered. The remaining pigs were fed to approximately 200 lb. then slaughtered.

Pigs in trial 3 were not shrunk before slaughter since full weight was used to estimate cutting yield of the pigs remaining on the experiment.

A section consisting of the 10 th, 11 th, and 12 th ribs was cut from the left loin of each carcass and frozen. It was later partially thawed and the longissimus dorsi muscle separated from external fat and bone and then ground. Crude fat was determined directly as ether extract.

The data from trial 3 were subjected to analysis of variance by the method of fitting constants. Differences between means required for significance were calculated as described by Snedecor (1956).

Partial efficiency coefficients were calculated as:

$$
\frac{\text { additional gain in lean cuts }}{\text { additional protein consumed }}
$$

for the respective increments of protein between the low and medium and between the medium and high protein regimes. 


\section{Trials 4 and 5}

All animals used in the fourth trial and one-third of those used in the fifth trial were purebred Durocs; the others in the fifth trial were Duroc $\mathrm{x}$ Yorkshire crossbreds. In each trial, three barrows and three gilts of similar bodyweight were selected from each of three litters. The pigs chosen were then allotted to treatment randomly within sex and litter. Each protein sequence was fed to a total of three barrows and three gilts in each trial.

In addition to collection of carcass data previously described, the specific gravity of the trimmed right ham was obtained from the weight of the ham in air, divided by the difference of the weight in air and the weight in water. Muscles and fat of the ham were then separated carefully by using a scalpel. The percentage of fresh weight as muscle and as fat was calculated on the basis of the weight of the intact ham. Color of ham and loin was scored by two observers according to Wisconsin Agricultural Experiment Station Bulletin, 1963.

Muscle tissue dissected from the right ham was prepared for moisture, ether extract and protein determination. A section of the longissimus dorsi between the 10 th and 12 th ribs was used for moisture and ether extract determination. Samples were prepared and analyzed according to A.O.A.C. (1960) methods.

A group of 10 students and professors, ranging in age from 22 to 30 years, constituted the taste panel. The meat used by the panel was a previously frozen section of right loin from the 4 th to the 10 th rib. The loin was thawed at $36^{\circ} \mathrm{F}$ for $48 \mathrm{hr}$. and then roasted at a constant temperature of $350^{\circ} \mathrm{F}$ until the meat thermometer reached $185^{\circ} \mathrm{F}$. A section 1.5 in. thick was cut from the posterior end of the loin for Warner-Bratzler shear evaluation. Three, 0.5 -in. diameter cores of lean meat were obtained from this 1.5 -in. section, and three readings were made on each core. The shear value was calculated from the average of the nine readings from each loin. The meat for taste acceptability was cut in cubes approximately 0.4 in. $^{3}$ from the central portion of the loin, and throughout the panel each member received meat from the same relative position in each loin. Each member was asked to score the desirability of meat on four attributes, tenderness, juiciness, flavor and overall acceptability. Each attribute was scored from 1 to $8 ; 1$ representing extreme undesirability, and 8 extreme desirability. The taste score was calculated from the average scores of the 10 members.

Data from the two trials were pooled after homogeneity of variance was tested (Steel and Torrie, 1960). Duncan's multiple-range test was applied to compare treatment means (Steel and Torrie, 1960). 


\section{Results and Discussion}

\section{EFFECTS ON CARCASS COMPOSITION}

Results of the five trials are generally in agreement. Increasing dietary protein increased yield of lean cuts and decreased per cent fat cuts. It appeared that lean cuts from carcasses of pigs fed either the high- or medium-protein diets contained a higher proportion of lean than similar cuts from carcasses of pigs fed the low-protein diet. Bellis and Taylor (1961) found such a relationship.

\section{Trial 1}

The carcasses in this trial were less meaty than the market now demands. For example, only three of the pigs had longissimus dorsi muscles measuring 4 sq. in. or more and, based on U.S.D.A. standards, there were only five U. S. No. 1 carcasses. Despite this, there were responses to the protein levels used. Carcasses from pigs fed either the medium- or highprotein rations yielded a greater $(\mathrm{P}<.01)$ per cent of lean cuts than those fed the low-protein ration (Table 3). Differences between the carcasses of pigs fed the high- and medium-protein levels were slight. Carcasses from gilts yielded a greater $(\mathrm{P}<.01)$ percentage of lean cuts than barrows.

Carcasses from pigs fed either high- or medium-protein ration yielded a smaller $(P<.05)$ proportion of fat cuts (belly, jowl, leaf fat, fatback and fat trim) than those from the pigs fed the low-protein ration.

\section{TABLE 3}

\section{Effect of Dietary Protein Level and Sex on Carcasses of Twelve 200-Lb. Durocs. Trial 1}

\begin{tabular}{lccccc}
\hline & \multicolumn{3}{c}{ Protein level $^{\mathrm{a}}$} & \multicolumn{2}{c}{ Sex $^{\text {b }}$} \\
\cline { 2 - 6 } & High & Medium & Low & Gilts & Barrows \\
\hline Per cent lean cuts & 52.7 & 52.9 & $50.8^{* *}$ & $54.5^{* *}$ & 49.8 \\
Per cent fat cuts & 35.0 & 35.5 & $38.3^{*}$ & 33.4 & $39.1^{* *}$ \\
L. dorsi area, sq. in. & 3.9 & 3.7 & 3.5 & $4.1^{* *}$ & $3.4^{*}$ \\
Average backfat thickness, in. & 1.5 & 1.5 & $1.8^{*}$ & $1.4^{* *}$ & 1.7 \\
\hline
\end{tabular}

$*(\mathrm{P}<.05)$.

$* *(\mathrm{P}<.01)$.

a 4 animals per mean.

${ }^{\mathrm{b}} 6$ animals per mean.

Explanation: " $\mathrm{P}<.05$ " is called a "probability statement" and it means that the odds are less than 5 in 100 that these differences among the means (averages) would have occurred by chance alone. 
The difference due to sex wats significant $(P<.01)$, with the gilt carcasses containing less fat cuts than the barrow carcasses.

Cross-sectional area of the longissimus dorsi muscle increased with dietary protein level and the cross-sectional area of longissimus dorsi muscles was greater $(\mathrm{P}<.01)$ for gilts than for barrows.

Average backfat thickness was decreased $(P<.05)$ with the first 3 per cent increase in dietary protein level but the second increase did not appear to have further influence. The average backfat thickness of gilt carcasses was less $(\mathrm{P}<.01)$ than that of barrow carcasses.

\section{Trial 2}

Per cent lean cuts was non-significantly greater for pigs fed the medium- and high-protein levels (Table 4) than for the low group.

TABLE 4 Effect of Dietary Protein Level, Sex and Strain on Carcasses
of Eleven 200-Lb. Pigs. Trial 2

\begin{tabular}{|c|c|c|c|c|c|c|c|}
\hline & \multicolumn{3}{|c|}{ Protein level } & \multicolumn{2}{|c|}{ Sex } & \multicolumn{2}{|c|}{ Strain } \\
\hline & High & Medium & Low & Gilts & Barrows & $\begin{array}{l}\text { York- } \\
\text { shires }\end{array}$ & $\begin{array}{l}\text { Cross- } \\
\text { breds }\end{array}$ \\
\hline Per cent lean cuts & 54.2 & 54.7 & 52.2 & 53.8 & 53.5 & 50.8 & $56.9 * \%$ \\
\hline Per cent fat cuts & 33.6 & 32.9 & 34.8 & 32.8 & 34.9 & 36.3 & $30.7^{* *}$ \\
\hline $\begin{array}{l}\text { L. dorsi area, sq. in. } \\
\text { Average backfat }\end{array}$ & 5.0 & 4.6 & 4.4 & $5.0^{*}$ & 4.2 & $4.3^{*}$ & 5.1 \\
\hline thickness, in. & 1.29 & 1.33 & 1.38 & 1.28 & 1.40 & $1.49 * *$ & 1.15 \\
\hline
\end{tabular}

$*(P<.05)$.

$* *(\mathrm{P}<.01)$.

"Data missing for one crossbred barrow on high protein.

There was no appreciable differences due to sex. In trial 1 the gilt carcasses had a significantly greater $(\mathrm{P}<.01)$ proportion of lean cuts than the barrow carcasses. This is in agreement with Bruner et al. (1958) and Cahill et al. (1960). The lack of a significant difference between barrows and gilts in trial 2 may be associated with confinement of the barrows in metabolism crates since this led to food restriction (vide infra). The carcasses from the crossbred pigs yielded a greater $(\mathrm{P}<.01)$ proportion of lean cuts than those from the Yorkshires.

Gilts had larger $(\mathrm{P}<.05)$ longissimus dorsi area than barrows. Also, crossbreds had larger $(\mathrm{P}<.05)$ longissimus dorsi area than Yorkshires. The effect of protein level was less evident. 


\section{Trial 3}

The pigs in trial 3 did not grow as rapidly as those in previous trials. This was partly due to bacterial scours in the early part of the trial and to several weeks of sub-freezing weather.

Increasing dietary protein level increased the per cent lean cuts from carcasses of pigs slaughtered at $200 \mathrm{lb}$. (Table 5). Those fed the high and medium rations did not differ significantly from each other. Gilt carcasses yielded a greater $(\mathrm{P}<.05)$ proportion of lean cuts than barrow carcasses.

At 75 and $125 \mathrm{lb}$., per cent lean cuts varied directly with dietary protein levels, but differences were small compared to the standard deviations of the means. Four of the six gilts slaughtered at $125 \mathrm{lb}$. had longissimus dorsi muscles measuring in excess of 4 sq. in.

The second increase in dietary protein resulted in a significant $(\mathrm{P}<.01)$ decrease in per cent ether extract of the 10 th to 12 th rib section of the longissimus dorsi muscle of carcasses of 200-lb. pigs (Table 6). The longissimus dorsi muscle sections from gilt carcasses contained a smaller

\section{TABLE 5}

Effect of Dietary Protein Level and Sex on Carcasses of Thirty-Six Pigs. Trial 3

\begin{tabular}{|c|c|c|c|c|c|c|c|c|c|c|}
\hline & \multicolumn{6}{|c|}{ Protein lerel } & \multicolumn{4}{|c|}{ Sex } \\
\hline & \multicolumn{2}{|c|}{ High } & \multicolumn{2}{|c|}{ Medium } & \multicolumn{2}{|c|}{ Low } & \multicolumn{2}{|c|}{ Gilts } & \multicolumn{2}{|c|}{ Barrows } \\
\hline $\begin{array}{l}\text { Per cent } \\
\text { lean cuts }\end{array}$ & Mean & $\begin{array}{l}\text { Std. } \\
\text { dev. }\end{array}$ & Mean & $\begin{array}{l}\text { Std. } \\
\text { der. }\end{array}$ & Mean & $\begin{array}{l}\text { Std. } \\
\text { dev. }\end{array}$ & Mean & $\begin{array}{l}\text { Std. } \\
\text { dev. }\end{array}$ & Mean & $\begin{array}{l}\text { Std. } \\
\text { dev. }\end{array}$ \\
\hline $200 \mathrm{lb}$ & 53.6 & & 52.5 & & $50.4 *$ & & $53.1^{*}$ & & 51.2 & \\
\hline $125 \mathrm{lb}$. & 56.6 & 2.9 & 56.3 & 1.5 & 55.3 & 2.8 & 57.1 & 2.5 & 55.0 & I. 6 \\
\hline $75 \mathrm{lb}$ & 60.4 & 1.0 & 59.4 & 0.9 & 58.2 & 1.2 & & & & \\
\hline
\end{tabular}

Per cent fat cuts

$200 \mathrm{lb} . \quad 34.3$

$125 \mathrm{lb} . \quad 27.2$

34.1

37.1

$34.1^{*}$

36.2

$75 \mathrm{lb}$.

22.9

3.0

27.8

1.6

27.7

1.4

26.0

29.0

0.8

L. dorsi area, sq. in.

\begin{tabular}{rrrrrrrrrrr}
200 lb. & 4.4 & & 4.6 & & 4.2 & & $4.7 *$ & 4.1 & \\
125 lb. & 3.9 & 0.5 & 3.6 & 0.5 & 3.6 & 0.5 & 4.0 & 0.5 & 3.4 & 0.4 \\
75 lb. & 2.7 & 0.3 & 2.7 & 0.4 & 2.6 & 0.1 & & & & \\
\hline
\end{tabular}

Average backfat thickness, in.

\begin{tabular}{|c|c|c|c|c|c|c|c|c|c|c|}
\hline $200 \mathrm{lb}$. & 1.3 & & 1.2 & & $1.5^{*}$ & & $1.3^{*}$ & & 1.4 & \\
\hline $125 \mathrm{lb}$. & $1.0^{\mathrm{a}}$ & 0.05 & 1.0 & 0.10 & 1.1 & 0.10 & $1.0^{\mathrm{a}}$ & 0.15 & 1.0 & 0.02 \\
\hline
\end{tabular}


$(\mathbf{P}<0.1)$ per cent ether extract than those from barrow carcasses and those from Durocs contained more $(\mathrm{P}<.01)$ ether extract than those from crossbreds. At 125 and $75 \mathrm{lb}$. ether extract varied with treatment.

Kauffman (1960) inclicated that marbling (measured in this trial as ether extract) is one of the most important factors influencing eating quality of pork. Ether extract varied inversely with protein level; however, ether extract was influenced more by strain than by diet. Should protein level be increased in practice, it may still be possible to maintain adequate marbling by selection.

Gain in lean cuts (Table 6) could be estimated for each period in trial 3. Gain in lean cuts varied directly with dietary protein level in the first and last periods but from 75 to $125 \mathrm{lb}$. there was a significant $(\mathrm{P}<.01)$ inverse relationship. From 75 to $200 \mathrm{lb}$. the gilts gained more in lean cuts than the barrows and this difference was significant $(P<.01)$ for the period from 75 to $125 \mathrm{lb}$.

Protein level did not affect weight of heart, amount of total nitrogen per milliliter of blood serum, or red cell count. There was a non-significant tendency for 75 -lb. pigs to have higher $\mathrm{N}$ levels in the serum than older pigs. Weights of livers from 200-1b. pigs fed the high-protein ration were heavier than those from pigs fed either the medium- or low-protein ration. Robison (ca. 1928) found that protein level influenced liver weights.

\section{Trials 4 and 5}

With the higher protein levels, the pigs had leaner carcasses with less backfat, larger longissimus dorsi muscle areas, a greater percentage of lean cuts, a lower proportion of fat cuts and a higher percentage of separable ham muscle (Table 7).

The specific gravity of the trimmed ham appeared to be a valid index for measuring carcass leanness. A significant linear relationship existed between the specific gravity of the trimmed ham and the per cent of lean cuts $(r=0.68, P<.01)$, the per cent of fat cuts $(r=-.70$, $\mathrm{P}<.01)$, the percentage of separable muscle of the ham $(r=0.59$, $\mathrm{P}<.01)$, and the percentage of separable fat of the ham $(r=-.64$, $P<.01)$. Standal $(1965)$ reported that specific gravity of the hams was the most potent single variable for predicting per cent lean $(\mathrm{r}=0.80)$ and per cent fat $(\mathrm{r}=-.83)$ in the hams. Brown et al. (1951) and Holme et al. (1963) used specific gravity of the carcass as a measure of fatness or leanness.

The color score was not significantly different among treatments. 


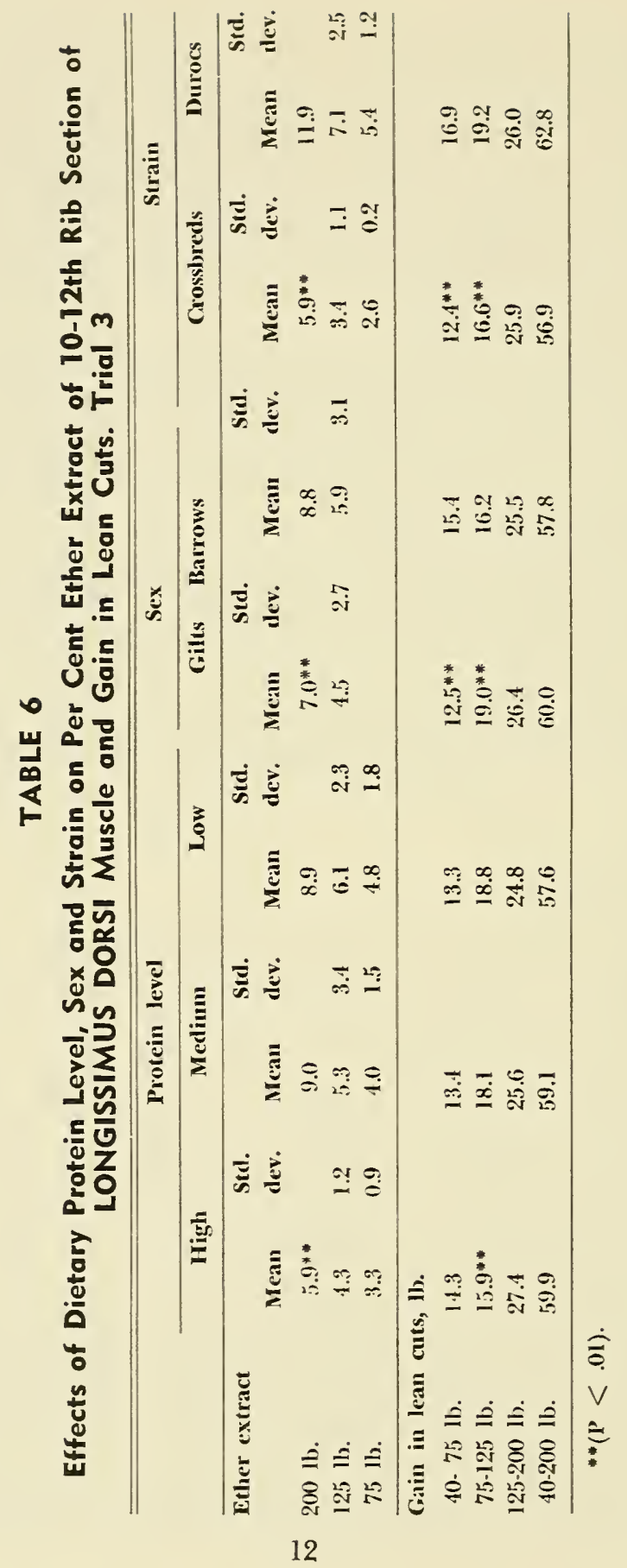


The Effect of Dietary Protein Level on Feedlot Performance and Carcass Characteristics

\begin{tabular}{|c|c|c|c|}
\hline \multirow{2}{*}{ Items } & \multicolumn{3}{|c|}{ Protein level } \\
\hline & Higlı & Medium & Low \\
\hline No. of animals & 12 & 12 & 12 \\
\hline Initial wt., lb. & 53.6 & 56.9 & 55.3 \\
\hline Final wt., lb. & 203.5 & 202.9 & 203.3 \\
\hline Days on trial & $93.3^{\mathrm{a}}$ & $92.0^{\mathrm{a}}$ & $102.5^{\mathrm{b}}$ \\
\hline Daily gain, lb. & $1.61^{\mathrm{a}}$ & $1.59^{n}$ & $1.43^{\mathrm{b}}$ \\
\hline Feed consumption, lb. & $523^{\mathrm{a}}$ & $551^{a, b}$ & $571^{b}$ \\
\hline Feed consumed/gain in wt. & $3.48^{\mathrm{a}}$ & $3.77^{\mathrm{a}, \mathrm{b}}$ & $3.87^{\mathrm{b}}$ \\
\hline Feed consumed/gain in lean cuts & $9.02^{n}$ & $9.83^{\mathrm{a}, \mathrm{b}}$ & $10.28^{b}$ \\
\hline Protein consumption, lb. & $86.4^{a, r}$ & $74.3^{\mathrm{b} \cdot \mathrm{e}}$ & $59.8^{\mathrm{d}}$ \\
\hline Protein consumed/gain in wt. & $0.58^{\mathrm{a}, \mathrm{c}}$ & $0.5 \mathrm{l}^{\mathrm{b}}$ & $0.40^{\mathrm{a}, \mathrm{d}}$ \\
\hline Protein consumed/gain in lean cuts & $1.49^{\mathrm{c}}$ & $1.23^{\mathrm{a}}$ & $1.00^{\mathrm{b}, \mathrm{d}}$ \\
\hline Dressing, \% & 73.6 & 74.0 & 74.8 \\
\hline Carcass length, in. & 28.9 & 28.5 & 29.0 \\
\hline Backfat thickness, in. & 1.34 & 1.42 & 1.50 \\
\hline L. dorsi area, in. ${ }^{2}$ & $4.43^{a}$ & $4.17^{\mathrm{a}, \mathrm{b}}$ & $3.80^{\mathrm{b}}$ \\
\hline Lean cuts \% (carcass basis) & $53.4^{4}$ & $5 \mathrm{I} .6^{\mathrm{x}, \mathrm{b}}$ & $50.3^{\mathrm{b}}$ \\
\hline Lean cuts, \% (live wt. basis) & $39.6^{2}$ & $38.6^{\mathrm{a}, \mathrm{b}}$ & $37.8^{\mathbf{b}}$ \\
\hline Fat cuts, \% (carcass basis) & $34.9^{\mathrm{e}}$ & $37.2^{\mathrm{a}}$ & $38.3^{\mathrm{b}, \mathrm{d}}$ \\
\hline Fat cuts, \% (live wt. basis) & $26.0^{2}$ & $27.8^{\mathrm{a}, \mathrm{b}}$ & $28.8^{\mathrm{b}}$ \\
\hline Specific gravity of trimmed right ham & $1.062^{\circ}$ & $1.061^{\mathrm{c}}$ & $1.057^{\mathrm{a}}$ \\
\hline Separable muscle of the trimmed ham, $\%$ & 64.2 & $62.0^{c, d}$ & $60.2^{\mathrm{d}}$ \\
\hline Separable fat of the trimmed ham, \% & $21.2^{\mathrm{n}}$ & $22.4^{\mathrm{a}, \mathrm{b}}$ & $24.7^{\mathrm{b}}$ \\
\hline
\end{tabular}

${ }^{a, b}$ Data on the same line bearing different superscript letters differ significantly $(\mathbf{P}<.05)$.

c,dData on the same Iine bearing different superscript letters differ significantly $(\mathrm{P}<.0 \mathrm{I})$.

The ether extract of the longissimus dorsi and of the muscle of the trimmed right ham varied inversely with the protein level $(\mathrm{P}<.01)$. The differences observed in the contents of crude protein and ash were not significant, if corrected to a fat-free basis (Table 8). Vipperman et al. (1963) pointed out that an increase in moisture and ash in the muscle is accomplished by a decrease in fat. A.S.A.P. (1963) observed that the chemical composition of fat-free mature animals is practically constant.

The results of the taste desirability and shear evaluation are shown in Table 9. Only tenderness of the meat was detected to be significantly 


\section{The Effect of Dietary Protein on Chemical Composition of Right Ham Muscles and L. DORSI}

\begin{tabular}{|c|c|c|c|}
\hline \multirow[b]{2}{*}{ Items } & \multicolumn{3}{|c|}{ Protein level } \\
\hline & High & Medium & Low \\
\hline No. of animals & 12 & 12 & 12 \\
\hline \multicolumn{4}{|l|}{ Ham muscles; fresh basis } \\
\hline Moisture, \% & $72.7^{\mathrm{a}}$ & $72.3^{\mathrm{a}, \mathrm{b}}$ & $71.7^{\mathrm{b}}$ \\
\hline Ether extract, \% & $5.81^{\mathrm{a}, \mathrm{c}}$ & $6.66^{\mathrm{b}, \mathrm{c}}$ & $7.92^{\mathrm{d}}$ \\
\hline Protein, \% & $21.0^{\mathrm{a}}$ & $21.0^{\mathrm{n}}$ & $20.1^{\mathrm{b}}$ \\
\hline Ash, \% & $1.06^{\mathrm{a}, \mathrm{c}}$ & $1.02^{b}$ & $1.01^{\mathrm{d}}$ \\
\hline \multicolumn{4}{|l|}{ Ham muscles; fat free basis } \\
\hline Moisture, \% & $77.2^{2}$ & $77.5^{\mathrm{a}, \mathrm{b}}$ & $77.9^{\mathrm{b}}$ \\
\hline Protein, \% & 22.3 & 22.5 & 21.9 \\
\hline Ash, \% & 1.12 & 1.09 & 1.10 \\
\hline \multicolumn{4}{|l|}{ L. dorsi } \\
\hline Moisture, \% & $71.1^{\mathrm{a}, \mathrm{c}}$ & $70.2^{\mathrm{b}}$ & $69.3^{\mathrm{a}, \mathrm{d}}$ \\
\hline Ether extract (dry matter basis), \% & $19.8^{c}$ & $25.0^{\mathrm{d}}$ & $31.0^{\circ}$ \\
\hline
\end{tabular}

\section{TABLE 9}

The Effect of Dietary Protein Level on Shear Value and Taste Panel Evaluation of 4th to 10th Rib Section of Right Loin

\begin{tabular}{lccc}
\hline \multirow{2}{*}{\multicolumn{1}{c}{ Items }} & \multicolumn{3}{c}{ Protein level } \\
\cline { 2 - 4 } No. of animals & High & Medium & Low \\
Shear reading, lb. & 12 & 12 & 12 \\
Tenderness score & 5.98 & 6.02 & 5.20 \\
Juiciness score & $5.43^{c}$ & $5.63^{c}$ & $5.93^{\text {b,d }}$ \\
Flavor score & 5.00 & 5.23 & 5.28 \\
Overall score & 5.73 & 5.93 & 5.77 \\
\hline
\end{tabular}

${ }^{a, b}$ Data on the same line bearing different superscript letters differ significantly $(\mathrm{P}<.05)$.

c,dData on the same line bearing different superscript letters differ significantly $(\mathbf{P}<.01)$.

different $(\mathrm{P}<.05$ between the medium- and low-protein groups, and $\mathrm{P}<.01$ between the high-and low-groups). There was a tendency to favor the meat from the pigs fed low-protein diets. There were significant correlations between tenderness and other items. The partial correlation 
coefficients between tenderness and juiciness, flavor, overall score and shear force reacling are $0.48,0.44,0.72,-.68$, respectively. Kauffman et al. (1964) indicated that an increase in intramuscular fat in pork improved the flavor, tenderness and juiciness of the cooked pork. Henry et al. (1963) pointed out that the tenderness of pork was highly correlated with intramuscular fat $(r=0.37)$ and with juiciness $(r=0.63)$, and intramuscular fat was slightly correlated with flavor $(r=0.23)$. In this experiment, the ether extract content was significantly correlated with juiciness $(r=0.56)$ and overall score $(r=0.34)$. The data suggest that selection for intramuscular fat and other quality traits might well be included in indexes so that inadequate intramuscular fat does not result when the use of high-protein diets is economical.

\section{EFFECTS ON GAIN AND EFFICIENCY}

\section{Trials 1 and 2}

Data are summarized in Table 10. Differences in feed efficiency were significant $(\mathrm{P}<.05)$ in trial 2.

Results of the classical nitrogen balance study in trial 2 are shown in Table 11. Except for the second period, the high-protein barrows retained the most nitrogen, whereas the low-protein barrows retained the highest proportion of the apparently absorbed nitrogen. (In the second period high ambient temperatures caused reduced feed intake, especially in low- and high-protein pigs.)

\section{TABLE 10}

\section{Effect of Diefary Protein Level on Gain and Efficiency Measures. Trials 1 and 2}

\begin{tabular}{|c|c|c|c|c|c|c|}
\hline & \multicolumn{6}{|c|}{ Protein level } \\
\hline & \multicolumn{2}{|c|}{ High } & \multicolumn{2}{|c|}{ Medium } & \multicolumn{2}{|c|}{ Low } \\
\hline & Trial 1 & Trial $2^{a}$ & Trial 1 & Trial 2 & Trial 1 & Trial 2 \\
\hline Av. daily gain, lb. & 1.5 & 1.7 & 1.5 & 1.5 & 1.4 & 1.4 \\
\hline $\begin{array}{l}\text { Feed per pound gain, lb. } \\
\text { Feed per pound gain }\end{array}$ & 3.5 & 3.0 & 3.3 & 3.3 & 3.5 & 3.6 \\
\hline lean cuts, lb. & 9.6 & 7.6 & 9.2 & 8.3 & 9.9 & 9.5 \\
\hline $\begin{array}{l}\text { Protein per pound gain } \\
\text { lean cuts, lb. }\end{array}$ & 1.71 & 1.34 & 1.36 & 1.25 & 1.21 & 1.10 \\
\hline $\begin{array}{l}\text { Partial efficiency coefficients } \\
\text { First increment } \\
\text { Second increment }\end{array}$ & & $\begin{array}{l}\text { Tri } \\
+19 \\
+3\end{array}$ & $\begin{array}{l}1 \\
.7 \% \\
.9 \%\end{array}$ & & $\begin{array}{l}\text { Tri } \\
+1 \\
+3\end{array}$ & $\begin{array}{l}2 \\
.9 \% \\
9 \%\end{array}$ \\
\hline
\end{tabular}

"Data missing for one crossbred barrow on high protein. 
TABLE 11

\section{Effect of Dietary Protein Level on Nitrogen Retention in Six ${ }^{2}$ Barrows. Trial 2}

\begin{tabular}{|c|c|c|c|c|c|}
\hline & \multirow{2}{*}{$\begin{array}{l}\text { Pigs } \\
\text { per } \\
\text { item }\end{array}$} & \multicolumn{3}{|c|}{ Protein level } & \multirow{2}{*}{$\begin{array}{l}\text { Difference required for } \\
\text { significance at the } 5 \% \\
\text { level of probability }\end{array}$} \\
\hline & & High & Medium & $\overline{\text { Low }}$ & \\
\hline \multicolumn{6}{|c|}{$\begin{array}{l}\text { Nitrogen retained, } \\
\text { grams per day at: }\end{array}$} \\
\hline $85 \mathrm{lb}$ & 2 & $13.4^{\mathrm{a}}$ & 11.6 & 10.6 & 9.2 \\
\hline $120 \mathrm{lb}$. & 2 & 8.4 & $13.5^{*}$ & 7.4 & 4.1 \\
\hline $170 \mathrm{lb}$. & 2 & $16.4^{a}$ & 14.2 & 7.7 & 19.6 \\
\hline \multicolumn{6}{|c|}{$\begin{array}{l}\text { Per cent of apparently } \\
\text { digested nitrogen } \\
\text { retained at: }\end{array}$} \\
\hline $85 \mathrm{lb}$ & 2 & $33.8^{2}$ & 41.8 & 39.4 & 13.8 \\
\hline $120 \mathrm{lb}$. & 2 & 24.1 & 34.3 & 30.5 & 10.2 \\
\hline $170 \mathrm{lb}$. & 2 & $35.4^{2}$ & 36.6 & 28.9 & 24.7 \\
\hline
\end{tabular}

$*(\mathrm{P}<.05)$.

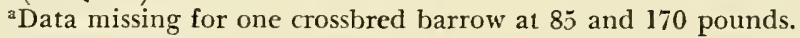

The major limitations of nitrogen balance by the slaughter method appear to be (1) possible sampling errors in estimating the initial composition of experimental animals and (2) the cost of separating cuts into lean and fat tissue or of grinding the entire carcass. The slaughter balance method has a great advantage in that performance of the pigs is not influenced by the restraint and reduced feed intake associated with the classical nitrogen balance technique.

The validity of the classical nitrogen balance technique for determining dietary protein requirements for growing-finishing swine is questionable for the purpose of this experiment. Under the conditions of the experiment it was impossible to get any restrained animal to ingest as much feed as self-fed, unrestrained pigs. It is generally accepted that efficiency of protein utilization is influenced by level of protein intake. Therefore, protein requirements determined by pigs fed a limited amount of feed would not be directly applicable to unrestrained pigs fed ad libitum.

A related limitation of the classical balance study is the possible effect on carcass composition. In trial 2 the barrows, which were periodically confined in metabolism crates, produced carcasses which did not differ significantly from littermate gilts receiving the same diet from self feeders. Gilt carcasses would be expected to yield a greater proportion of lean cuts than barrow carcasses (Cahill et al., 1960 and Bruner et al., 1958; also results of trials 1 and 3 of this study). 
McMeekan (1940) and Clausen (1959) found that restricted energy intake will influence carcass composition and it is possible that restriction of feed intake was the only causative factor imposed by restraint in metabolism crates. Mitchell (1939) and Lassiter et al. (1956) found inconsistencies between growth and balance studies.

In the trial reported here, feed efficiency was lower during the collection period than when pigs were not restrained. It appears that classical nitrogen balance should not be relied upon for extrapolation to carcass traits of ad libitum-fed pigs if restraint must be incorporated (cf. Becker and Harnisch, 1958).

The effect of periodic restraint of 2 barrows and 3 gilts compared to an unrestrained littermate pair was tested in a separate mock collection trial using 10 crossbred pigs from a single litter. Lean cuts averaged 52.9 per cent for the restrained animals and 50.9 per cent for controls. This difference was not significant, perhaps because it was not possible to kill the pigs at identical weights. However, when adjusted by covariance for difference in slaughter weight, confinement caused a significant $(\mathrm{P}<.01)$ reduction in fat cuts.

The partial efficiency coefficient for the second increment of ration protein in trial 2 (Table 10) cannot be adequately explained.

\section{Trial 3}

The outcome of trial 3 may have been influenced by slaughtering the first pigs to reach 75 or $125 \mathrm{lb}$. The most rapidly growing pigs were not allowed to reach market weight, thus influencing average daily gain (Table 12). This situation existed for all treatments. The difference in strain in the beginning was expected since starting weights were not the same.

TABLE 12

Effect of Dietary Protein Level, Sex and Strain on Average Daily Gain, Lb. Trial 3

\begin{tabular}{|c|c|c|c|c|c|c|c|}
\hline \multirow{2}{*}{$\begin{array}{l}\text { Weight } \\
\text { Rauge, lb. }\end{array}$} & \multicolumn{3}{|c|}{ Protein level } & \multicolumn{2}{|c|}{ Sex } & \multicolumn{2}{|c|}{ Strain } \\
\hline & High & Medium & Low & Gilts & Barrows & Crossbreds & Durocs \\
\hline $40 \cdot 75$ & 1.09 & 1.08 & 1.02 & 1.03 & 1.09 & $1.13^{* *}$ & 0.98 \\
\hline $75-125$ & 1.55 & 1.48 & 1.48 & 1.43 & 1.57 & 1.59 & 1.38 \\
\hline $125-200$ & 1.52 & 1.70 & 1.47 & 1.56 & 1.56 & 1.61 & 1.45 \\
\hline $50-200$ & 1.34 & 1.43 & 1.30 & 1.34 & 1.39 & 1.44 & 1.29 \\
\hline
\end{tabular}

${ }_{*}(\mathrm{P}<.01)$ 
Pounds of feed required per $1 \mathrm{~b}$. gain (Table 13) was not significantly different. Pounds protein required per $\mathrm{lb}$. gain in lean cuts (Table 14) was significantly $(\mathrm{P}<.01)$ different for treatment and for sex. Protein consumed per pound gain varied directly with dietary protein level.

\section{TABLE 13}

Effect of Dietary Protein Level, Sex and Strain on Feed Required Per Pound Gain. Trial 3

\begin{tabular}{lccc}
\hline & \multicolumn{3}{c}{ Protein level } \\
\cline { 2 - 4 } & High & Medium & Low \\
\hline
\end{tabular}

Pounds feed per pound gain:

Av. by treatment,

sex and strain:

Crossbred gilts

50-200 lb.

3.48

3.34

4.06

Crossbred barrows

50-200 lb.

3.34

3.37

3.74

Duroc gilts

30-200 lb.

3.60

3.80

3.50

Duroc barrows

30-200 Ib.

3.50

3.50

3.60

\section{TABLE 14}

Effect of Dietary Protein Level, Sex and Strain on Pounds Dietary

Protein Required Per Pound Gain in Lean Cuts and on Partial Efficiency Coefficients of Thirty-Six Pigs. Trial 3

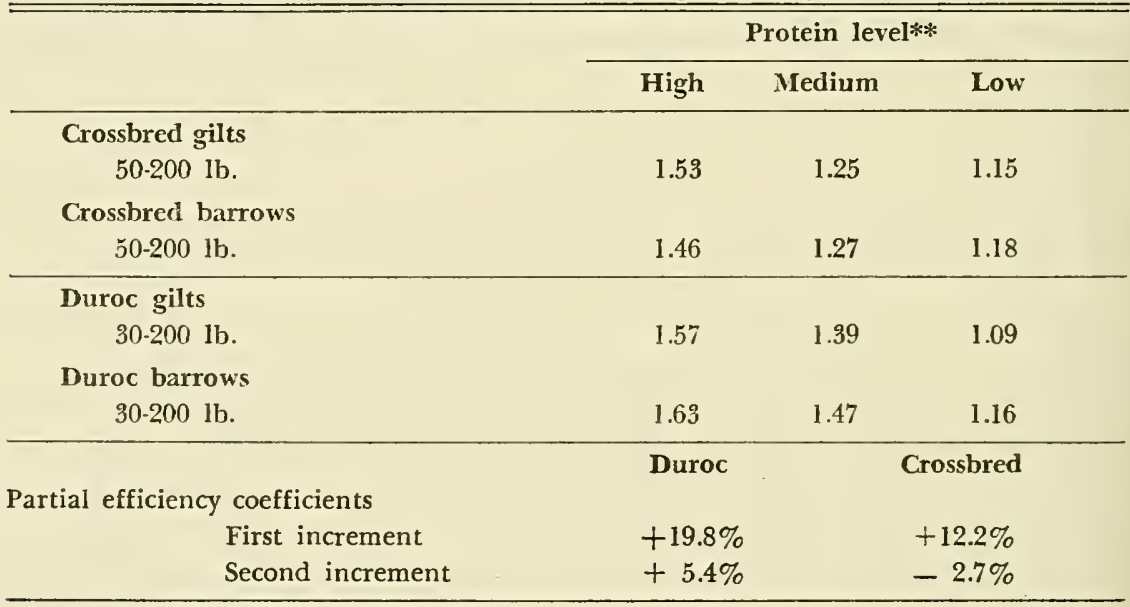

** Overall effect of protein significant at 1 per cent level. 
Pounds of feed required per pound gain in lean cuts were 8.8, 9.2, and 9.9 for high, medium, and low, respectively, but these were not significantly different. (These values include lean cuts of pigs killed at light weights as well as those killed at $200 \mathrm{lb}$., but the pigs in the trial grew more slowly and were less efficient than usual.)

\section{Trials 4 and 5}

Pigs on the higher protein levels had more rapid rates of gain, improved feed efficiency and consumed significantly less feed per pound gain in lean cuts (Table 7).

General. Gain in lean cuts varied directly with dietary protein level but conformed to the concept of diminishing returns. Protein per pound gain (protein efficiency ratio) was lowest for the low-protein regimen. However, feed per pound gain in lean cuts was highest for the low-protein regimen. Despite the lack of significance in trials 1-3 with the number of animals studied, the latter measure merits attention. Admittedly, belly, jowl, etc. have economic value and a market may fail to make full compensation for the increased meatiness of carcasses from high-protein-fed pigs.

A physical rather than economic solution to the ration protein (input) : carcass protein (output) problem is elusive. Perhaps it is impossible unless a minimum partial efficiency coefficient is specified in lieu of the classical "point of diminishing returns" in which input and output are equated in dollars.

Although the physiologically optimal protein levels may be higher than the high-protein diets used in this study, the economically optimal level probably is below this point. Some workers (e. g. Wagner et al., 1963) have reported that higher protein levels also reduce the rate of gain which would result in added costs. In no case did the pigs fed the lowprotein diet make the most economical gains at 1961 feed ingredient prices. Moreover, if feed cost per pound gain in lean cuts is taken as the criterion, the low-protein level appears even less favorable.

In order to have large differences between treatment effects in this study the protein level of the various diets differed by three percentage points and, to keep the number of rations to a minimum, the dietary protein level was reduced by three percentage points each period. Perhaps smaller changes would be more in keeping with the pigs' physiological protein requirements. Changes of two percentage points may be acceptable to the feeder and the feed manufacturer. 


\section{Summary}

Five slaughter balance trials involving 108 weaned pigs were conducted to estimate the influence of three sequences of protein upon gain in trimmed lean cuts. The improvement in carcass merit was greatest for the first increment of ration protein and a tentative recommendation of 18 per cent, 15 per cent, 12 per cent crude protein for the periods weaning to $75 \mathrm{lb}$., 75 to $125 \mathrm{lb}$. and 125 to $200 \mathrm{lb}$, respectively, is offered.

The following changes were associated with increasing protein level; increased yield of lean cuts, increased longissimus dorsi muscle area, decreased yield of fat cuts, decreased backfat thickness and decreased ether extract of longissimus dorsi muscle.

The interactions between sex and protein level were significant in several instances and this, plus the well-known carcass differences, suggests that gilts may be able to utilize more protein, at a given level of efficiency, than barrows.

The changes in efficiency of production of lean cuts by pigs fed different levels of protein are presented and discussed. The increased gain in lean cuts associated with high ration protein levels conformed to the concept of diminishing returns. Decreased partial efficiency coefficients were obtained in 3 of 4 comparisons. This was reflected in decreased protein efficiency ratios. What may be more important is the fact that the feed required per pound gain in lean cuts continued to decrease as the protein level was increased and feed cost at 1961 ingredient prices followed a similar pattern.

The lowest protein level was associated with more intramuscular fat and greater tenderness of the meat. Selection for adequate intramuscular fat is suggested so that the use of high-protein diets does not lead to lowered product acceptability.

\section{Literature Cited}

A.S.A.P. 1963. Techniques and procedures in animal production research. Am. Soc. An. Prod.

Becker, M. and S. Harnisch. 1958. Neve Utersuchungen uber die Gultigkert und Exaktheit von Stickstoffbilanzen bei Stoffwechselversuchen an lebenden Tieren. Archives Tieranahrung 8:309-320, 401-419. Cited in Nutr. Abs. and Rev. 29:1863, 4126. 1959.

Bellis, D. B. and J. Taylor. 1961. Nutritional factors affecting lean meat production in cutting pigs. An. Prod. 3:209.

Brown, C. J., J. C. Hillier and J. A. Whatley. 1951. Specific gravity as a measure of the fat of the pork carcass. J. Animal Sci. 10:I. 
Bruner, W. H., V. R. Cahill, W. L. Robison and R. F. Wilson. 1958. Performance of barrow and gilt littermate pairs at the Ohio Swine Evaluation Station. J. Animal Sci. 17:875.

Cahill, V. R., T. S. Teague, L. E. Kunkle, A. L. Moxon and E. A. Rutledge. 1960. Measurement of and ways of affecting sex-influenced performance of growingfinishing swine. J. Animal Sci. 19:1036.

Henry, W. E., L. J. Bratzler and R. W. Luccke. 1963. Physical and chemical relationships of pork carcasses. J. Animal Sci. 22:613.

Holme, D. W., W. E. Coey and K. L. Robinson. 1963. The prediction of pig carcass composition from measurements of carcass density. J. Agr. Sci. 61:9.

Kauffman, R. G. 1960. Pork marbling. Proc. of 13th Ann. Reciprocal Meat Conf. Clicago. p. 31 .

Kauffman, R. G., Z. L. Carpenter, R. W. Bray and W. G. Hoekstra. 1964. Biochemical properties of pork and their relationship to quality. J. Food Sci. 29:70.

Lassiter, J. W., S. W. Terrill, D. E. Becker and H. W. Norton. 1956. Protein levels for pigs as studied by nitrogen balance. J. Animal Sci. 15:392.

McMeekan, C. P. 1940. Growth and development in pig with special reference to carcass quality characteristics. J. Agr. Sci. 30:276.

McMeekan, C. P. 1941. Growth and development in the pig with special reference to carcass quality characteristics. J. Agr. Sci. 31:1.

Mitchell, H. H. 1939. Nutritional requirement of weanling pigs-coordination and summary. Proc. American Society of Animal Production.

Reciprocal Meat Conference. 1952. Report of the pork carcass evaluation committee. Proc. of 5th Ann. Reciprocal Meat Conf., Chicago. p. 119.

Robison, W. L., ca. 1928. Undated mimeograph. Effect of protein level on the cutout value of hogs. Ohio Agr. Exp. Sta.

Scherer, C. W. 1962. Estimation of optimum protein level in the diet of growingfinishing swine with emphasis on meatiness of carcass. M. S. Thesis. West Virginia University, Morgantown, W. Va.

Standal, N. 1965. Specific gravity and other carcass measurement as predictors of percent lean and fat in hams. Acta Agri. Scandinavica 15(1):65.

Vipperman, P. E., Jr., C. C. Brooks, R. F. Kelly, P. P. Graham and H. R. Thomas. 1963. Effect of dietary lysine level on muscle size and composition in swine. J. Animal Sci. 22:674.

Wagner, G. R., A. J. Clark, V. W. Hays and V. C. Specr. 1963. Effect of protein-energy relationships on the performance and carcass quality of growing swine. J. Animal Sci. 22:202.

Wisc. Agr. Exp. Sta. 1963, Pork quality standards. Special Bul. 9. Madison, Wisc. 




\section{、}


